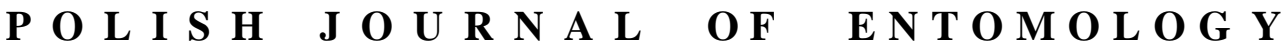

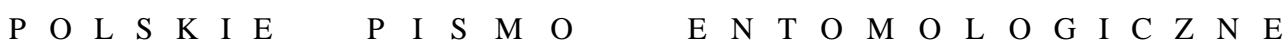

VOL. 85: 147-176

Lublin

30 March 2016

DOI: $10.1515 /$ pjen-2016-0008

\section{Towards a revision of the genus Otiorhynchus GERMAR, 1822 subgenus Choilisanus REITTER, 1912 with descriptions of new species (Coleoptera: Curculionidae: Entiminae: Otiorhynchini)}

\section{PIOTR Z. BIAŁOOKI*}

Plant Health and Seed Inspectorate, ul. Na Stoku 48, 80-874 Gdańsk, Poland

\begin{abstract}
New species of the subgenus Otiorhynchus (Choilisanus) are described: pectorosus sp. n., octangularis sp. n., impetrativus sp. n., megapterygius sp. n., analemmus sp. n., thermophilus sp. n., robustisetis sp. n., umbraticus sp. n., sculptiventris sp. n., plagigerulus sp. n., and imperspicabilis sp. n., all from Asia Minor.
\end{abstract}

KEY WORDS: Curculionidae, Otiorhynchus, Choilisanus, new species, Turkey.

\section{INTRODUCTION}

The subgenus Choilisanus REITTER, 1912 belongs to one of the most extensive subgenera within Otiorhynchus: currently 45 species are known (MAGNANO \& AlONSO-ZARAZAGA 2013, DAVIDIAN \& KESKIN 2010, DAVIDIAN \& GÜLTEKIN 2015a, 2015b, BIAŁOOKI 2015b). The systematic position of this large group within the genus Otiorhynchus, its definition, as well as its species composition are all in urgent need of revision. I embarked on such a project several years ago, and the revision is now nearly complete. However, as new species are still being published, publication of the revision at the present moment would be premature. In the meantime, this paper presents descriptions of new species.

\footnotetext{
*Corresponding author: og-gdynia@piorin.gov.pl, pbialooki@poczta.onet.pl
} 


\section{Acknowledgements}

I would like to express my sincere thanks to everyone who allowed me to work with collections, loaned specimens, helped in the literature search, and showed great hospitality during my visits to the collections: Lutz BEHNE, Senckenberg Deutsche Entomologische Institut, Müncheberg, Germany; Stanislav BENEDIKT, Plzeň, Czech Republic; Ottó MERKL, Gyözö SzÉl and Attila PodlussánY, Hungarian Natural History Museum, Budapest, Hungary; Marek WANAT, University of Wrocław, Poland.

\section{MATERIAL AND METHODS}

Virtually all the descriptions are based on specimens collected by myself; the materials relating to one species were kindly loaned to me by Stanislav BENEDIKT. The width of the rostrum is consistently defined as the pterygial span, i.e. the distance between the outer margins of the pterygia, even though the basal breadth of the rostrum in front of the eyes may be longer in some cases. Other basic morphological terms, "frons" in particular, were defined in BIAŁOOKI (2015a). "Eyes/pterygia projecting" means "eyes/pterygia extending the outline of the head/rostrum in the dorsal view" respectively. Multilayered photographs were taken with a Leica M205C stereomicroscope with an attached JVC KYF75 digital camera and subsequently montaged using the AutoMontage software of Syncroscopy. Labels are always cited verbatim; " " separates the labels of a given specimen, whereas "l" separates different specimens; ht denotes "holotype".

Acronyms: BENE - the collection of Stanislav BENEDIKT, Plzeň, Czech Republic; BIAL - the collection of P.Z. BIAŁOOKI, Sopot, Poland; HNHM - the collection of the Hungarian Natural History Museum, Budapest, Hungary; MNHW - the collection of the Museum of Natural History of the University of Wrocław, Poland; PODL - the collection of Attila PoDlussánY, Budapest, Hungary.

\section{RESULTS}

Subfamily Entiminae

Tribe Otiorhynchini

Genus Otiorhynchus GERMAR, 1822

Subgenus Choilisanus REITTER, 1912 (type species Otiorhynchus balcanicus STIERLIN, 1861) 


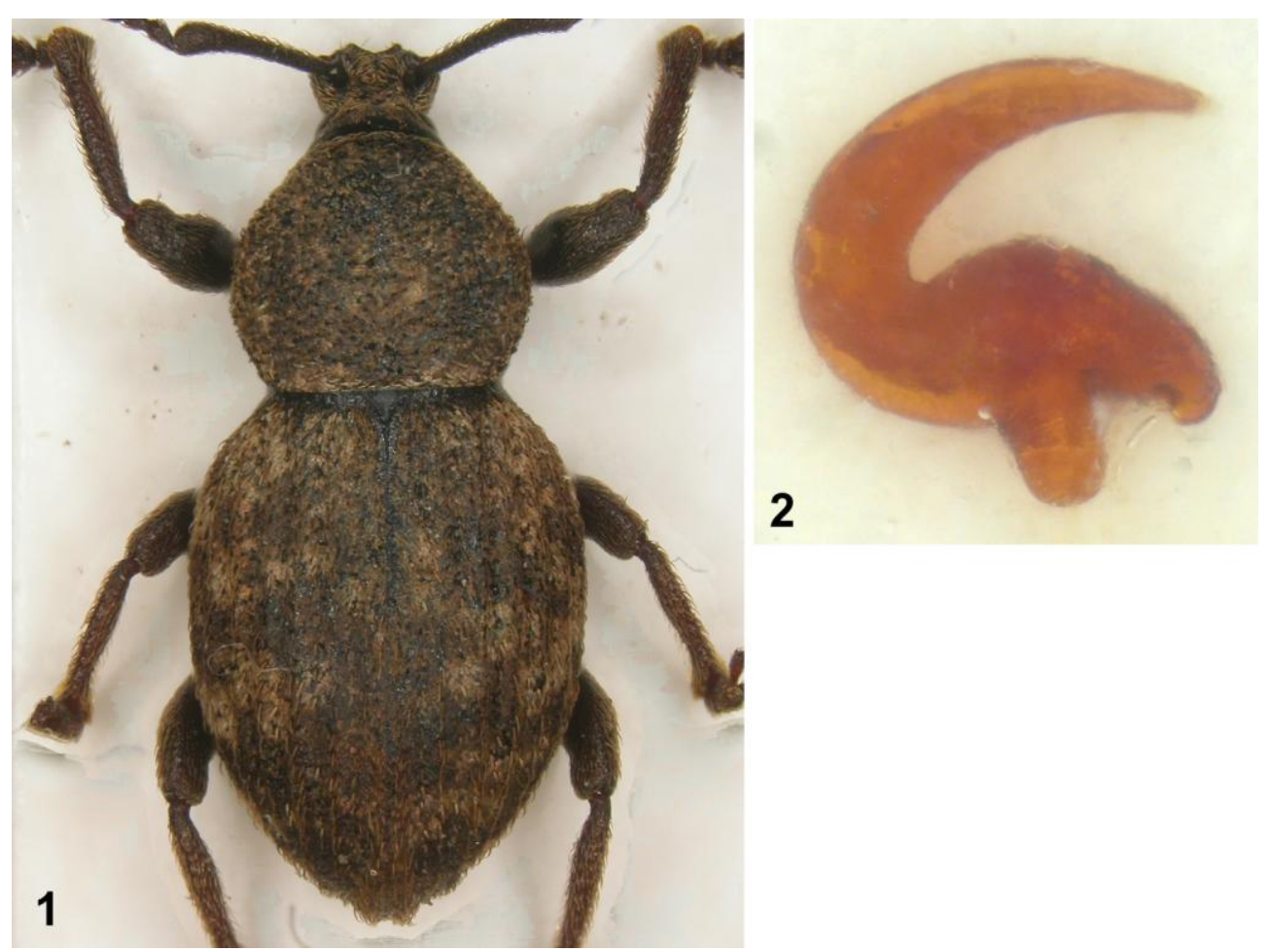

Figs 1, 2. O. pectorosus: 1 - female, 2 - spermatheca.

Otiorhynchus (Choilisanus) pectorosus sp. n.

(Figs 1, 2)

\section{Material examined}

Holotype female, dissected: 12.06.2003 N Turkey, Egribel Geçidi, S Giresun, leg. P. BIAŁOOKI [BIAL]. Paratypes: as ht, 3 exx. $\backslash$ label as ht, but 12.06.2010, 1 ex. [BIAL] Turkey b.or. 3.07.1998; Giresun Dağlar1, 2100 m; Yavuzkemal p. Dereli env.; sifting in Rhododendron; S. BENEDIKT leg., 1 ex.। Turkey b.or. 4.07.1998; Giresun Dağları, 1600 m; Tamdere p. Dereli env.; sifting in Fagetum; S. BENEDIKT leg., 5 exx. [BENE; BIAL].

\section{Diagnosis}

The new species (Fig. 1) is most probably closely related to O. terrifer STIERLIN, 1884, from which it differs in the prothorax, which is unusually large, heavily convex, very strongly rounded at the sides, strikingly broader than the small narrow head; the pronotal disc is covered with much less coarse punctation; pterygia strongly projecting; spermatheca 
with well-developed ramus. Males differ from females in the smaller, more slender body and slightly larger epistomal horns.

\section{Description (female)}

Body length 4.6-6.4 mm (ht $6.4 \mathrm{~mm}$ ); black, legs and antennae dark brown, in part black.

Head distinctly separate from basal part of rostrum; frons narrow, covered with dense, recumbent and distinctly semi-erect broad, weakly elongate scales obscuring integument almost completely; frons fovea much bigger than surrounding punctation, elongate; eyes moderately big, subisodiametric, weakly convex, hardly projecting, $1.45 \times$ narrower than frons, in lateral view much approaching the frons level.

Rostrum strongly transverse, $1.3 \times$ broader than long, basal portion slightly tapered; pterygia large, strongly projecting, pterygial span $1.5 \times$ wider than minimum width of rostrum; dorsal wall moderately expanded backwards, flat, covered with dense, small punctures, and moderately dense, recumbent, slightly raised, broad, moderately elongate scales, and with much longer, thin, subparallel-sided hair-like scales; median sulcus broad, shallow, hardly perceptible; median keel thin, low, weakly expressed; dorsal wall before antennal insertion rather strongly linearly divergent apicad, covered with dense punctation, punctures much bigger than on hind part of dorsal wall of rostrum, and with sparse, long, thin semi-erect hair-like scales; epistome symmetrical, short, hollowed, angles clearly more elevated; anterior margin excised.

Antennae slightly more slender than in $O$. terrifer; scape straight; first funicle segment distinctly longer than second, $1.8 \times$ longer than broad; second segment $1.5 \times$ longer than wide; segments 3-4 subisodiametric; segments 5-7 gradually more transverse, $7^{\text {th }}$ moderately transverse; club twice as long as wide, as long as 3.5 distal funicle segments combined.

Pronotum exceptionally large, strongly swollen, $1.15 \times$ broader than long, very strongly convex longitudinally; strongly rounded at sides, clearly broadest behind middle; anterior margin much narrower than base; disc covered with rather unclear tubercles, in part reduced almost to small, deep punctures; interspaces narrower than diameter of tubercles, with rather dense, minute punctures; thin, hardly convex median carina well perceptible, covered with similar pinholes as on interspaces of tubercles; vestiture consisting of recumbent, small, subisodiametric, light-brown and brown, overlapping scales completely obscuring integument, and with thin, parallel-sided, weakly arcuate, somewhat raised hairlike scales.

Elytra $1.25 \times$ longer than broad, egg-shaped, distinctly broadest before middle, apical portion much stronger narrowed than basal, subacute; apical declivity less convex than in O. terrifer; striae narrower than interstices, interspaces somewhat longer than diameter of 
punctures; interstices slightly convex, with irregular 1-3 rows of long, semi-erect, parallelsided, arcuate, brown hair-like scales; both striae and interstices covered with dense, imbricate, recumbent, light-brown and brown scales creating unclear irregular maculation.

All femora unarmed; fore tibiae straight, dorsal margin broadly rounded apically, not expanded outwards, ventral margin with a few minute spines; fore and middle tibiae with single, hind legs with two short tibial spurs; tarsi broad, stout, second segment strongly transverse; third much broader than preceding segment; onychium rather short, robust, its projecting portion distinctly shorter than length of third segment.

Spermatheca (Fig. 2) with well-developed ramus, somewhat swollen corpus; cornu long, curved, tapering.

Male differs from female in much smaller body; smaller, less convex prothorax; epistomal horns somewhat better developed; outer margin of fore tibia apex less rounded distally.

\section{Ecology}

All specimens collected at locus typicus (altitude ca 2200- $2300 \mathrm{~m}$ amsl) were found under stones on alpine meadows, or sifted from ground litter amongst grass.

\section{Etymology}

The specific epithet is the Latin adjective meaning "having a large breast"; an allusion to the large prothorax.

\section{Otiorhynchus (Choilisanus) octangularis sp. n.}

(Figs 3, 4)

\section{Material examined}

Holotype female, dissected [left fore tibia and tarsus missing]: 19.05.2008 SW Turkey; Oyuklu Dağı; N Ermenek; leg. P. BIAŁOOKI [BIAL].

\section{Diagnostic description (female)}

Body length $6.9 \mathrm{~mm}$. The new species (Fig. 3), apparently very close to $O$. weisei REITTER, 1895 sharing with it very similar body relief and vestiture, differs from that species in: pterygia smaller, more regularly rounded in dorsal view, more distant from anterior margin of rostrum; antennal scape thicker, as long as funicle; club more elongate, regularly spindle-like, its first segment weakly arcuate basally, almost linearly expanded distad; eyes smaller, more convex; pronotal disc clearly flattened, in dorsal view somewhat octagonal, covered with minute, thin, hardly visible hair-like scales; elytra elongate, $1.4 \times$ 
longer than wide (in $O$. weisei $1.25 \times$ ), with apical declivity much less convex, less than perpendicular; elytral striae consisting of rather large, well separated punctures; interstices only a little broader than striae, semi matt, with minute punctation, and rather sparse, shining tubercles; fore tibiae with unrounded apex; tarsi distinctly stouter; spermatheca very similar to that in $O$. weisei, with moderately swollen corpus and minute nodulus; ramus not differentiated.

Male unknown.

\section{Ecology}

The only specimen known was collected under a stone on a high alpine steppe at ca $2300 \mathrm{~m}$ amsl.

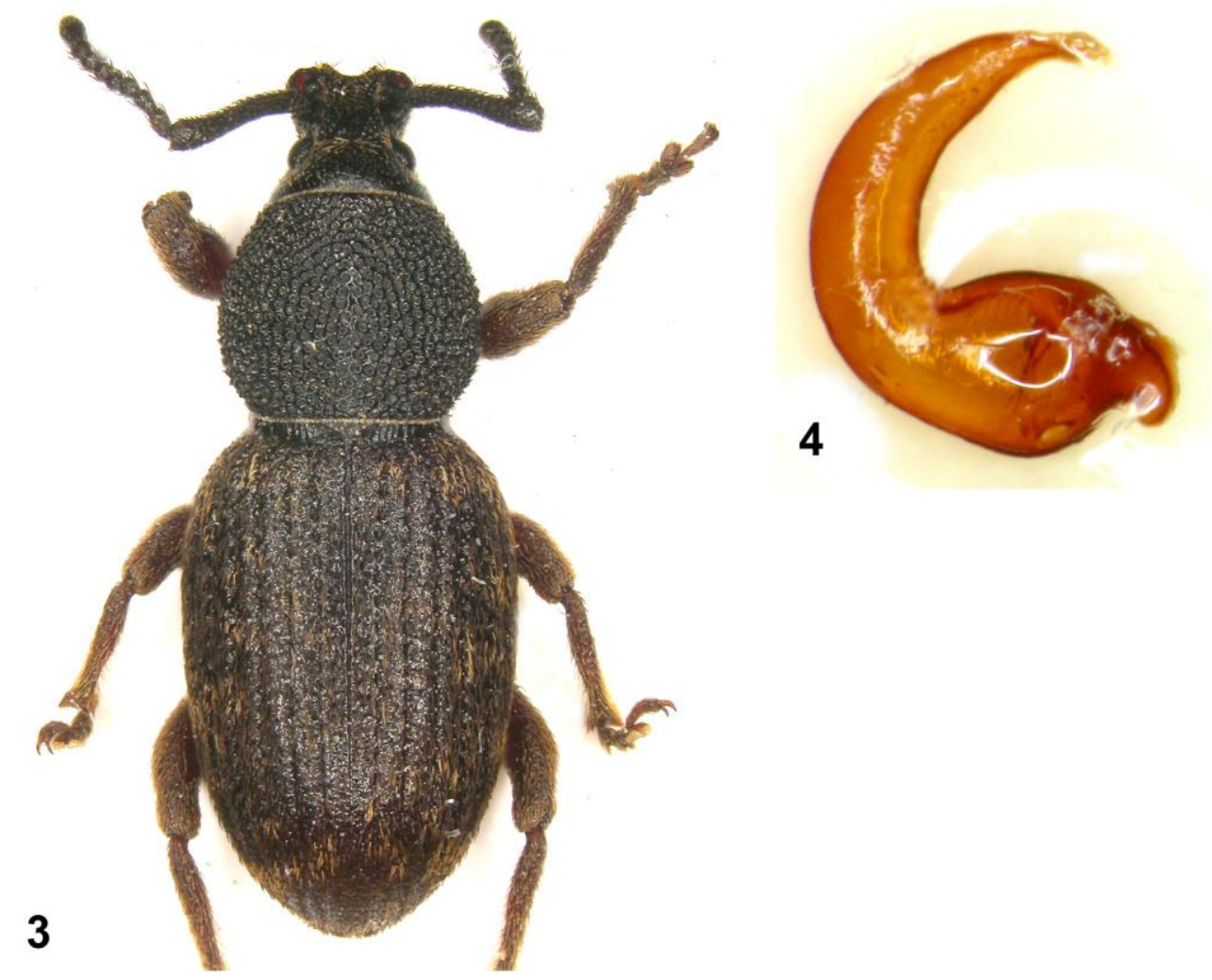

Figs 3, 4. Otiorhynchus octangularis: 3 - female, 4 - spermatheca. 


\section{Etymology}

The specific epithet (adjective) is derived from the Latin "octo" (= eight) and "angulus" (= angle), indicating the dorsal outline of the prothorax.

\section{Otiorhynchus (Choilisanus) impetrativus sp. n.}

(Figs 5, 6)

\section{Material examined}

Holotype male, dissected (left fore tarsus, except for first two segments, missing): 04.06.2010 W Turkey, Mt. 2334 m NW Hasanşeyh, W Konya, leg. P. BiAŁoOKI [BIAL]. Paratype: as ht, 1 ex. [BIAL].

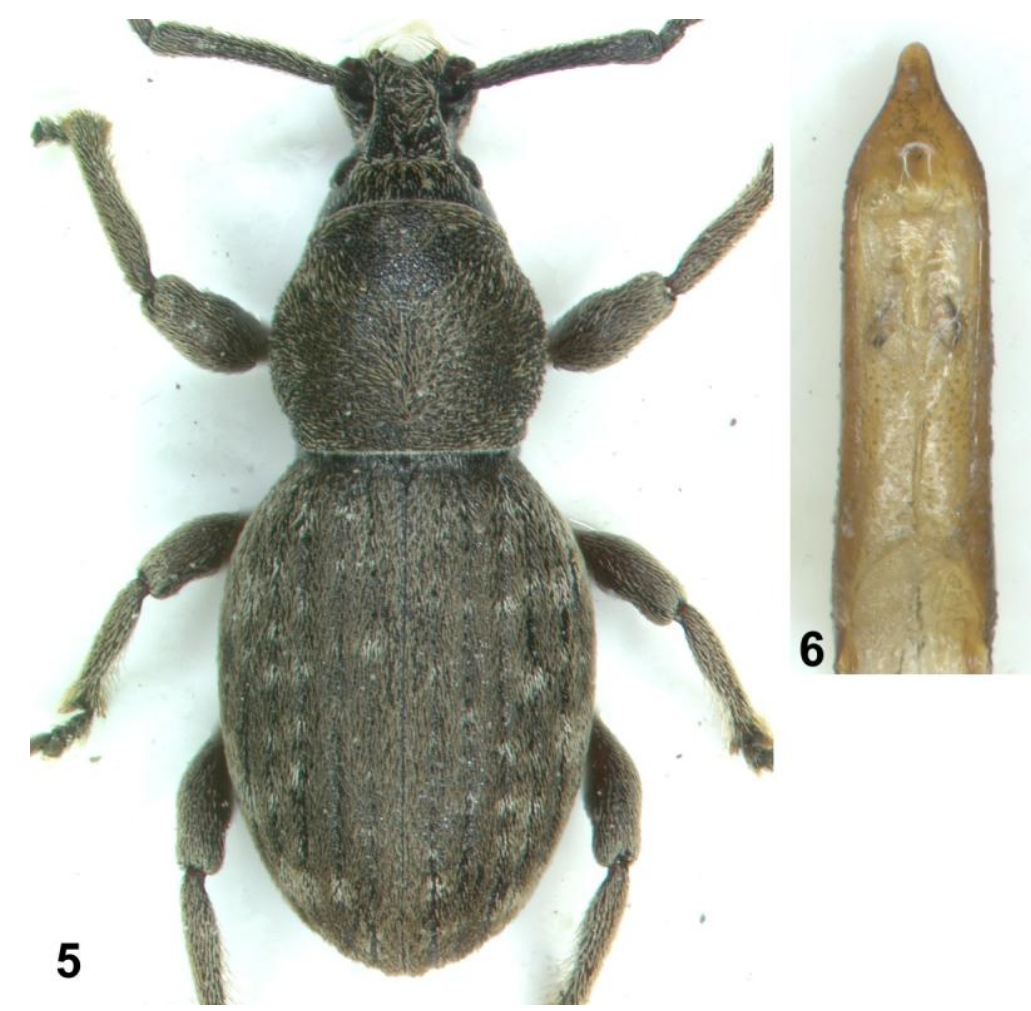

Figs 5, 6. Otiorhynchus impetrativus: 5 - male, 6 - aedagus. 


\section{Diagnosis}

O. impetrativus (Fig. 5) differs from O. megareus (the characters of the latter in parentheses) first of all in strikingly smaller body (O. megareus 7.8-8.6 mm); moreover in: elytra slightly less elongate; pronotum slightly more rounded at sides; head $2.1 \times$ broader than minimum rostrum width $(1.85 \times)$; pronotal disc with smaller, strongly flattened tubercles, in part reduced to punctation (all tubercles throughout pronotal disc welldeveloped, convex).

\section{Description (male)}

Body length 4.9-5.0 mm (ht $4.9 \mathrm{~mm}$ ), entirely dark brown, legs and antennae in part distinctly lighter.

Head transverse, strongly tapered together with basal part of the rostrum, temples somewhat shorter than longitudinal diameter of eye; frons entirely fused with basal part of rostrum, frons fovea large, elongate; eyes slightly elongate, rather small, its diameter half that of frons, hardly or not at all projecting, moderately convex.

Rostrum $1.15 \times$ wider than long; pterygia strongly projecting; hind half of dorsal wall rather strongly expanded backwards, with unclear, broadly rounded lateral margins; with not shallow, very broad median sulcus in its anterior part, backwards much narrowed; covered with light brown, moderately dense, slightly raised, elongate hair-like scales, and with rather large, somewhat elongate, dense punctures, interspaces shining; median keel low, thin, not broader than interspaces of punctation; anterior part of dorsal wall strongly, arcuately, concavely expanded anteriad, covered with dense, rough punctation, semi matt, and with scales smaller, much sparser; epistome subtriangular, strongly hollowed; epistomal angles elevated but horns not developed.

Antennae moderately robust; scape almost straight, rather weakly expanded apicad; first funicle segment somewhat longer and broader than second; segments 3-7 subisodiametric or slightly transverse; club elongate oval, twice as long as wide, as long as three distal funicle segments combined.

Pronotum slightly transverse, anterior margin slightly narrower than posterior; broadest in middle, covered with very dense, small, irregularly sized, strongly flattened tubercles in part reduced to punctation; vestiture consisting of dense, recumbent, elongate scales obscuring largely body surface.

Elytra moderately $(1.3 \times)$ elongate, weakly egg-shaped; at sides moderately, evenly arcuate, broadest slightly before middle; in lateral view weakly convex, disc flattened; apical declivity strongly vaulted; striae slightly impressed, within apical declivity much stronger, sutural interstice indistinctly elevated, punctures small, interspaces flat, smooth, subequally long as puncture diameter; interstices broad, $3 \times$ broader than striae, flat; striae 
and interstices uniformly, densely covered with minute, recumbent, lanceolate dark brown and greyish-brown scales showing unclear, irregular maculation.

Legs moderately robust, all femora unarmed; all tibiae with single spur and small mucro in part obscured by vestiture; dorsal margin of fore tibiae straight, apical portion weakly curved inwards; fore tarsi robust, short, second segment strongly transverse, onychium short, thick, its projecting portion subequally as long as preceding segment; hind tarsi distinctly longer and thinner than fore ones.

Ventral part of the body covered with moderately dense scales somewhat larger than elytral.

Aedeagus (Fig. 6) broadest at base, slightly tapered anteriad to the midlength, apical portion parallel-sided, apex subtriangular with concave sides; in lateral view moderately arcuate; apodemes distinctly longer than median lobe.

Female unknown.

\section{Ecology}

The two specimens were collected by sifting the ground litter on a dry mountain steppe at an altitude of ca $2100 \mathrm{~m}$ amsl.

\section{Etymology}

Derived from the Latin adjective "impetrativus" (= desired).

\section{Otiorhynchus (Choilisanus) megapterygius sp. n.}

(Fig. 7)

\section{Material examined}

Holotype: 14.05.2008 S Turkey; Alacabel Geçidi; NE Akseki; leg. P. BIAŁOOKI [BIAL]. Paratypes: as ht, 2 exx.; as ht but 12.05.2008, 6 exx. [BIAL].

\section{Diagnosis}

The most distinctive features of the new species are: an exceptionally large lateroventral excision between the apical and basal parts of the rostrum; a very narrow dorsal wall of the rostrum; elytral interstices very wide, quite flat; vestiture perfectly recumbent, including the whole apical declivity, consisting of true, broad, lanceolate scales obscuring the body almost completely.

The new species (Fig. 7) is only somewhat similar to O. megareus but differs strongly from that species in a smaller body; a much larger latero-ventral rostrum excision; pterygia 


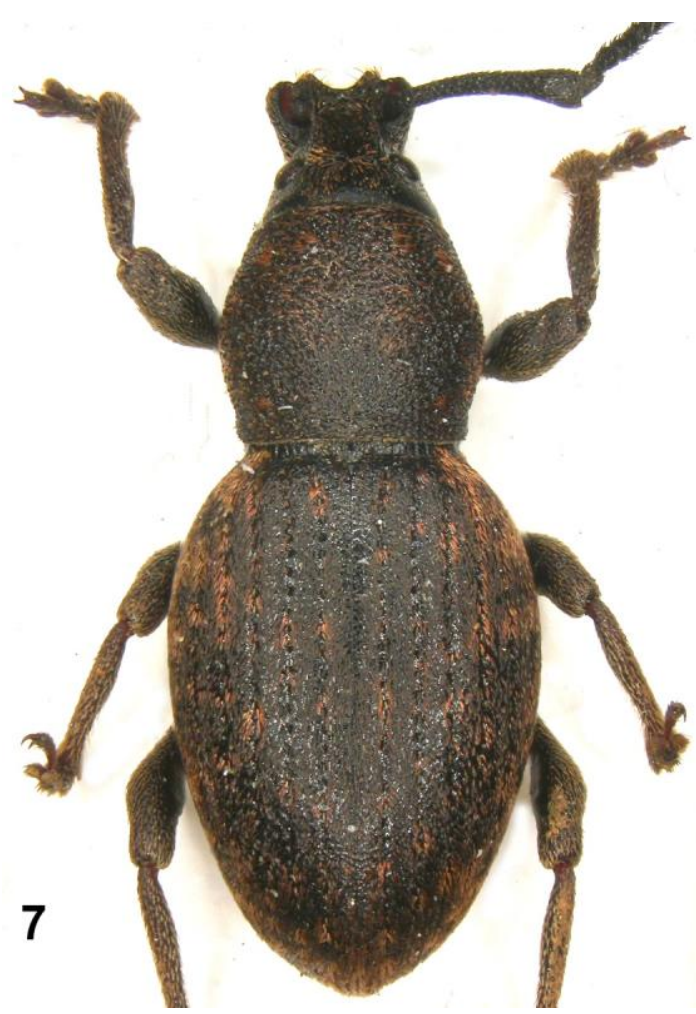

Fig. 7. O. megapterygius, female.

$1.6 \times$ broader than the minimum rostrum width; distinctly smaller eyes, more convex, not projecting, $2 \times$ shorter than frons; a strikingly narrower dorsal wall of the rostrum; a smaller frons fovea; stouter antennae, funicle segments 3-7 subisodiametric; egg-shaped elytra, interstices completely flat, striae indistinctly impressed.

\section{Description (female)}

Body length 7.4-8.1 mm (ht 7.4 mm); entirely dark brown, legs and antennae slightly lighter.

Head strongly tapered, together with basal part of rostrum forming joint cone; eyes not projecting, rather small, subcircular, moderately convex; frons twice as broad as eye diameter; frons fovea somewhat larger than surrounding punctation.

Rostrum slightly transverse, pterygia very strongly projecting, $1.6 \times$ broader than rostrum minimum width; latero-ventral excision between basal and anterior parts of rostrum extremely large; dorsal wall very narrow, at antennal insertion $2.4 \times$ narrower than 
pterygial span; anterior part of dorsal wall distinctly linearly expanded anteriad; epistome $\mathrm{v}$-shaped with broadly rounded proximal end, deeply hollowed.

Antennae stout; scape thick, weakly expanded apicad, only at apex somewhat thicker, markedly s-like arcuate; first two funicle segments subequally long, segments 3-7 subisodiametric; club elongate, $2.3 \times$ longer than wide, as long as three distal funicle segments combined.

Pronotum weakly transverse, broadest at middle, sides rather weakly arcuate, longitudinally weakly, transversally moderately convex; pronotal disc covered with very dense, minute tubercles bearing recumbent, brown elongate, lanceolate scales in great part obscuring body surface; lateral walls with much lighter scales.

Elytra almost $1.4 \times$ longer than wide, egg-shaped, apex somewhat acute; longitudinally weakly convex, disc almost flat, apical declivity strongly convex; striae indistinctly impressed, consisting of small, well expressed punctures, interspaces subequally as long as puncture diameter; interstices completely flat, $3-4 \times$ broader than striae, covered with irregular rugosity, microtubercles, punctures and with completely recumbent (also within apical declivity), brown, elongate, lanceolate scales obscuring body surface almost completely.

Legs rather short, moderately stout, all femora unarmed; fore tibiae at apex not expanding outwards; hind tibiae with single spur; tarsi moderately robust, second segment weakly transverse.

Ventral part of body covered with moderately sparse, elongate, narrow scales.

\section{Ecology}

All specimens were collected on the ground amongst herbaceous vegetation.

\section{Distribution}

So far, the new species is known only from the locus typicus of Büyükgözet Dağı in south-western Turkey.

\section{Etymology}

The specific epithet (adjective) is derived from the Greek "mega" (= large) and "pterygium", reflecting the extraordinarily large pterygia of the new species. 


\section{Otiorhynchus (Choilisanus) analemmus $\mathbf{s p .} \mathbf{n}$.}

(Figs 8, 9)

\section{Material examined}

Holotype male: 26.05.2006 W Turkey; Sivrihisar Dağları; E Sivrihisar; leg. P. BIAŁOOKI [BIAL]. Paratypes: label as ht but: 29.05.2007, 5 exx. [BIAL].

\section{Diagnosis}

The new species (Fig. 8) shares with $O$. thermophilus sp. n. a large, slender, similarly shaped body; it differs from that species in the strikingly better developed vestiture of dark brown scales and pale spots, pronotum with well-expressed analemma-like pattern; the more convex apical declivity; the first funicle segment much longer than the second; the apical portion of the dorsal margin of the fore tibia in the male narrow, clearly curved ventrad.

\section{Description (male)}

Body length $6.8-8.3 \mathrm{~mm}$ (ht $6.8 \mathrm{~mm}$ ); entirely dark brown to black.

Head strongly tapered, together with basal part of the rostrum forming common cone; covered with dense, small punctures, and with dense, small, narrow, recumbent, red-brown hair-like scales; frons clearly at angle to rostrum, $1.6 \times$ broader than eye diameter; frons fovea large, elongate, deep; eyes slightly elongate, small, moderately convex; temples somewhat shorter than eye diameter.

Rostrum transverse; pterygia large, pterygial span $1.5 \times$ broader than minimum width of rostrum; latero-ventral excision of the rostrum large; hind part of dorsal wall parallel-sided, with somewhat unclear margins; thin median keel and lateral sulci well expressed; covered with rather dense, narrow, recumbent scales, and with moderately large and dense punctures; anterior part of dorsal wall strongly, linearly divergent anteriad; epistome large, triangular, strongly hollowed.

Antennae stout; scape robust, slightly expanded apicad; first funicle segment clearly longer than second, twice longer than wide; second segment much shorter, $1.2 \times$ longer than broad; segments 3-7 subisodiametric; club moderately elongate, $2.3 \times$ longer than broad, as long as three distal funicle segments combined.

Pronotum large, slightly transverse, broadest at midlength, sides regularly, rather strongly arcuate; disc rather strongly convex transversally, covered with very dense, regularly convex, small tubercles, each with large puncture and scale clearly larger than on head and rostrum; very characteristic analemma-pattern of 12 spots of light scales sharply expressed. 


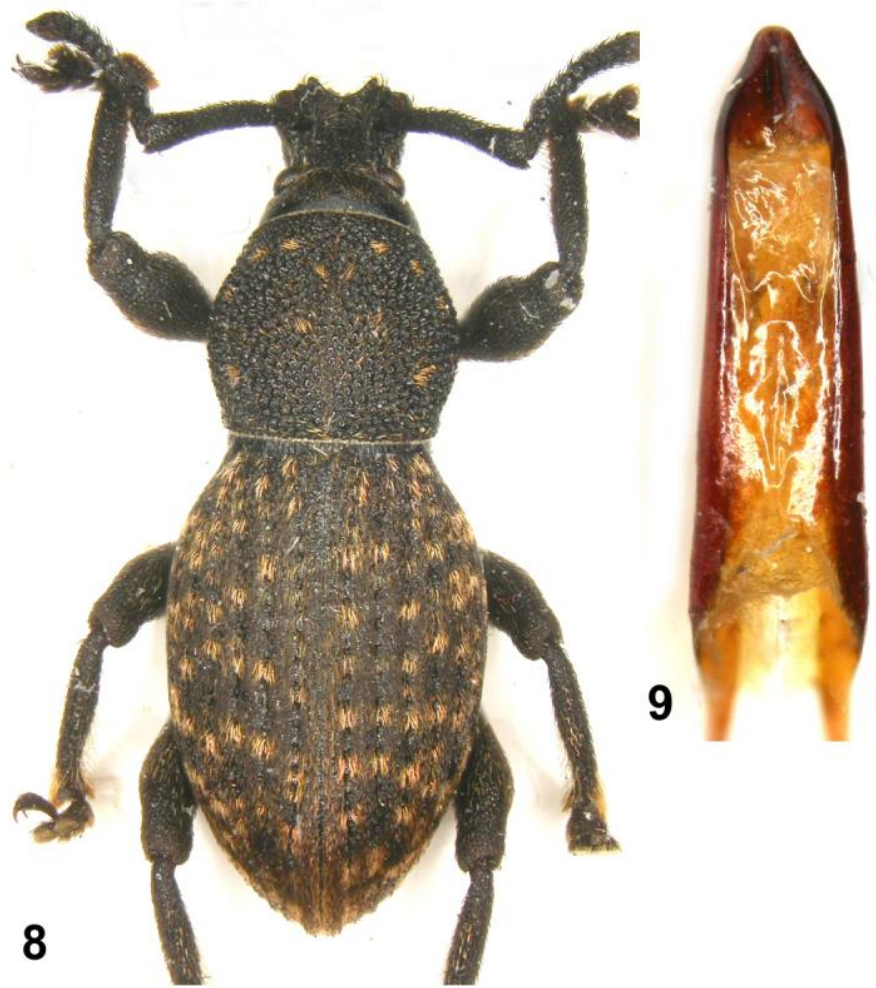

Figs 8, 9. O. analemmus: 8 - male, 9 - aedagus.

Elytra elongate, $1.45 \times$ longer than broad, at sides moderately arcuate, much stronger to somewhat acute apex; in lateral view weakly convex, base almost flat; apical declivity strongly convex, strial punctures larger than diameter of pronotal tubercles; interspaces as long as puncture diameter, with small, single, shining tubercle; interstices slightly broader than striae; both striae and interstices covered with very dense, recumbent, narrow, brown, light brown and yellow scales concealing body surface almost completely.

Legs long and stout; all femora unarmed; fore and middle femora with small mucro; tibial spurs 1-1-2; all tarsi short, stout; second segment subtriangular, rather strongly transverse.

Ventral part of the body covered with the same scales as on outer interstices, but much more sparse; anal ventrite strongly convex in basal part, apical portion distinctly impressed, inner margin with well-developed process.

Aedeagus (Fig. 8) very typical of the subgenus, weakly gradually tapering; apex short, top broadly rounded. 
Females differ from males in clearly more slender legs; elytra $1.3 \times$ broader than pronotum; hind tibiae without fringe of dense, apically curved hairs, with normal, sparse, straight setae; anal ventrite flat, with no process.

\section{Ecology}

All specimens collected on an extremely dry, warm, south-facing slope with scanty vegetation, predominantly covered with stones; found under stones or sifted from ground litter under Astragalus species.

\section{Etymology}

The specific epithet is an adjective coined from the Greek "analemma" (= a diagrammatic depiction of how the length of the shadow of a particular sundial changes throughout the year; having the shape of the infinity symbol $\infty$ ).

\section{Otiorhynchus (Choilisanus) thermophilus sp. n.}

(Figs 10, 11)

\section{Material examined}

Holotype male, dissected: 22.05.2007 SW Turkey; Aksivri Tepe; N Elmali; leg. P. BIAŁOOKI [BIAL]. Paratypes: as ht, 20 exx. [BIAL; HNHM; MNHW; PODL].

\section{Diagnosis}

The most distinctive character of $O$. thermophilus (Fig. 10) is the elytral vestiture, which consists of very short, sparse, recumbent hair-like scales not obscuring the body surface; large pterygia reaching the anterior margins of the epistome; elytral striae with vaguely visible punctures, with tubercles along its entire length; a relatively weakly convex apical declivity, the first interstice slightly swollen, higher than the surrounding interstices. It differs from O. glebius DAVIDIAN \& KESKIN, 2010 in the much smaller endophallic transfer apparatus, situated closer to the apices of the apodemes than to the base of the median lobe; well-developed, paired subapical structures; the first interstice along the apical declivity is clearly swollen, the slightly decurved apical declivity; the strikingly less developed elytral vestiture, consisting of very short (half the width of the interstices), recumbent, non-contiguous hair-like scales not at all obscuring body surface; slightly bigger and less convex pronotal tubercles, with the impunctate area usually well-developed; scarcely recognizable strial punctures, each interspace with a well-developed tubercle, not strikingly smaller than those on the interstices; scape subequally thick along its entire length; temples sparsely punctate, interspaces wider than the puncture diameter. 

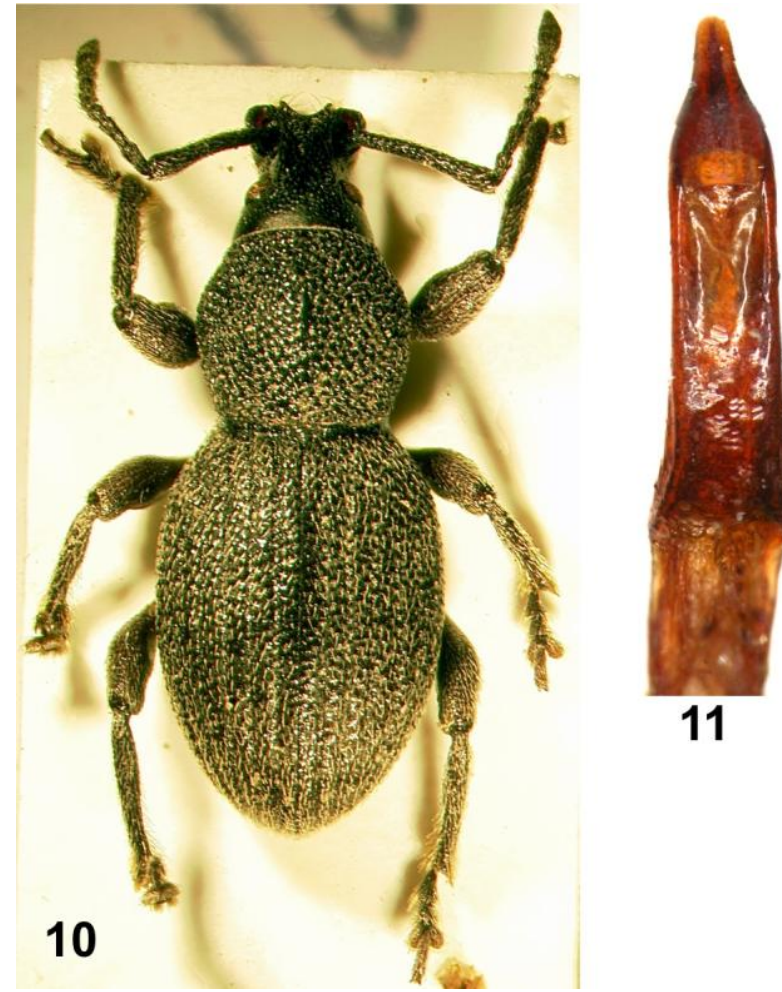

11

Figs 10, 11. O. thermophilus: 10 - male, 11 - aedagus.

\section{Description (male)}

Body length 5.4-8.1 mm (ht $5.9 \mathrm{~mm}$ ); entirely dark brown, nearly black.

Head together with basal part of rostrum creating common cone; vertex covered with moderately large, dense, very shallow punctures, interspaces covered with microsculpture, matt; frons at same level as rostrum, $1.7 \times$ wider than eye diameter; frons fovea large, deep, elongate; eyes small, longitudinal diameter slightly shorter than temple, distinctly convex, impressed, not at all projecting.

Rostrum somewhat transverse; pterygia large, indistinctly less projecting anteriad than epistome, span $1.75 \times$ wider than frons; epistome symmetrically subtriangular, deeply hollowed; anterior part of dorsal wall strongly divergent anteriad, evenly weakly impressed, covered with very dense, rather coarse irregular sculpture, vestiture consisting of sparse brown recumbent hairs; hind part of dorsal wall divergent backwardly (posteriorly lateral edges much less defined than in anterior half), covered with coarse longitudinal ribbing and irregular punctures, vestiture as on anterior part of dorsal wall. 
Antennae moderately robust; scape as long as funicle, straight, indistinctly thickened apicad; first two funicle segments $2 \times$ longer than wide each, first $2.2 \times$ longer than second; third segment slightly elongate; segments 4-6 slightly transverse; last segment subisodiametric but bigger than preceding; funicle covered with rather weakly semi-erect light brown setae; club $2.6 \times$ longer than wide, as long as 3 distal funicle segments combined.

Prothorax $1.15 \times$ broader than long, moderately convex, sides moderately arched, anterior margin somewhat narrower than base, broadest slightly before middle; disc covered with dense, contiguous, relatively big convex tubercles; small convex impunctate shining area slightly anteriad of centre well-developed; vestiture consisting of brown subrecumbent hair-like scales much longer than on frons; latero-ventral walls covered with similar tubercles but much less convex, hairs much shorter and sparser than on the disc.

Elytra $1.4 \times$ longer than wide, apical portion stronger narrowed; longitudinally weakly evenly convex, apical declivity weakly convex; striae narrow, indistinctly impressed, punctures small, ill-defined yet deep, interspaces subequally long as punctures diameter, each with small shining tubercle; interstices 2.5-3 $\times$ broader than striae, covered with dense irregularly arranged moderately convex shining tubercles distinctly bigger than strial ones; vestiture consisting of short recumbent sparse elongate bright brown scales broadest subbasally, tapered apicad, pointed, somewhat shorter, broader, and paler than pronotal; apical declivity covered with much more dense vestiture, striae stronger impressed.

Legs moderately robust; femora robust, unarmed, covered with hardly raised bright brown long hair-like scales; dorsal margins of fore tibiae straight, ventral margin weakly bisinuate, with long semi-erect setae; tibial spurs well-developed, 1-1-2; fore tarsi rather robust, second segment transverse; hind tarsi more slender, second segment hardly transverse.

Anal process short, broadly arched, less than semicircular.

Aedeagus (Fig. 11) rather strongly tapered basally, then parallel-sided, apex long and narrow.

Female differs indistinctly from male in slightly less robust legs and antennae, and first two ventrites not impressed.

\section{Ecology}

All specimens of the new species were collected under stones rather deeply embedded in the soil in a strongly insolated, dry spot covered with moderately sparse xerothermic grassy vegetation at an altitude of ca $2100 \mathrm{~m}$ amsl.

\section{Etymology}

The name refers to the xerothermic habitat of the new species. 

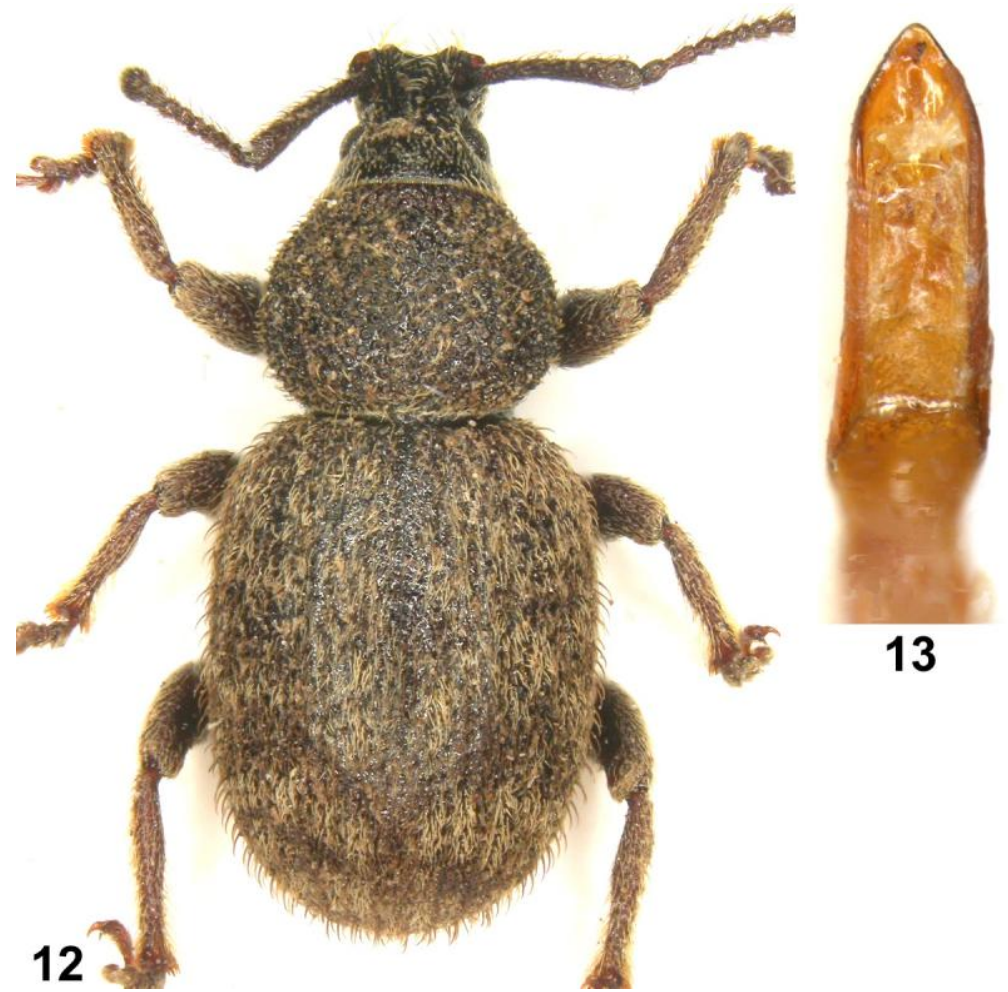

Figs 12, 13. O. robustisetis: 12 - male, 13 - aedagus.

Otiorhynchus (Choilisanus) robustisetis sp. n.

(Figs 12, 13)

\section{Material examined}

Holotype male, dissected: 08.06.2006 NW Turkey; Kocakirdağ Tepe; NW Emet; leg. P. BIAŁOOKI [BIAL]; Paratypes: label as ht, 6 exx. [BIAL].

\section{Diagnosis}

The new species (Fig. 12) is apparently close to O. brunneus GYLLENHAL, 1834; it differs from that species in the smaller body; much shorter elytra; the strong contrast between the long, semi-erect setae and the recumbent, much shorter hairs, the latter disposed in fairly well-defined maculation; the strongly transverse second tarsal segment; and the longer median lobe of the aedeagus. 
O. brunneus: the contrast between yellow-brown, semi-protruding, hair-like setae and recumbent, not much shorter hairs is hardly expressed; the maculation hardly expressed, if at all; second tarsal segment hardly transverse.

\section{Description (male)}

Body length 4.4-5.1 mm (ht $4.5 \mathrm{~mm}$ ); dark brown, legs and antennae somewhat paler.

Head together with basal portion of rostrum conically tapered; temples slightly shorter than eye diameter; frons fovea minute, hardly recognizable; eyes large, $1.7 \times$ narrower than frons, weakly elongate, distinctly convex, somewhat projecting.

Rostrum strongly transverse, pterygial span $1.3 \times$ broader than length of rostrum; pterygia moderately large, moderately projecting; hind part of dorsal wall short, broad, $1.25 \times$ narrower than frons, covered with coarse, dense, elongate punctures and with sparse, weakly elevated, brown hair-like scales, lateral margins unclear; shallow, unclear median sulcus with thin, somewhat unclear, low median keel; anterior part of dorsal wall distinctly expanded apicad, densely, coarsely punctate; epistome symmetrically triangular, relatively weakly hollowed, keels thin, hardly elevated.

Antennae rather thin, scape indistinctly arched; first funicle segment short, $1.8 \times$ longer than wide, much broader than next segment; second segment $2.2 \times$ longer than broad; segments 3-5 indistinctly elongate; segments 6-7 hardly transverse; club elongate, $2.1 \times$ longer than broad, somewhat longer than three distal funicular segments combined.

Pronotum large, robust, $1.25 \times$ broader than long, at sides strongly, evenly rounded, broadest indistinctly behind middle; longitudinally clearly convex, transversally moderately so; anterior margin indistinctly narrower than base; disc covered with small, dense, convex, apically flattened tubercles with apical puncture bearing distinctly semi-protruding, long, brown hair-like scale; latero-ventral walls covered with tubercles much less convex, and with much sparser recumbent or slightly elevated hairs.

Elytra short, $1.2 \times$ longer than broad, sides weakly arcuate, broadest in middle, apical portion very broadly rounded; in lateral view flattened in basal half, apical declivity very strongly convex; transversally strongly convex; striae thin, in part slightly impressed, punctures subequally big as pronotal tubercles, interspaces subequally long as puncture diameter; interstices 3-4 $\times$ broader than striae, flat; both striae and interstices covered with irregular subtle microrugosity and minute, weakly convex, sparse shining tubercles distributed irregularly, and with dense, recumbent, grey and light-brown, short hairs obscuring in large part body surface, creating unclear, irregular maculation, and with much longer, arcuate, strongly semi-protruding brown setae arranged densely, irregularly; contrast between recumbent and semi-erect scales sharply expressed; outer interstices exclusively with recumbent vestiture. 
Legs short, robust; all femora unarmed; fore tibiae straight, apex broadly rounded, indistinctly expanded outwards; apical portion of ventral margin with minute spines; hind legs with two tibial spurs; tarsi robust, second segment strongly transverse.

Ventral portion of the body covered with moderately dense, recumbent or slightly elevated hairs; anal ventrite $1.9 \times$ broader than long, basally clearly convex, apical impression distinctly expressed; process not developed.

Aedeagus (Fig. 13) $3.2 \times$ longer than wide; ring of tegmen very broad; parameres short.

Female differs from male indistinctly in slightly wider elytra; on average larger body; ventrites flat.

\section{Ecology}

The new species inhabits meadows within a subalpine coniferous forest.

\section{Etymology}

The specific epithet is coined from the Latin "robustus" (= stout, robust), and Latin "seta" (= seta, hair), reflecting the unusually robust elytral protruding setae.

\section{Otiorhynchus (Choilisanus) umbraticus sp. n.}

(Figs 14, 15)

\section{Material examined}

Holotype male, dissected: 16.05.2007 W Turkey; Boz Dağ; NE Ödemiş; leg. P. BIAŁOOKI [BIAL]. Paratypes: label as ht, 21 exx.I same, but 18.05.2010, 3 exx. [BIAL; HNHM; MNHW].

\section{Diagnostic description}

The most significant characters of the new species: elytral vestiture dense, consisting of semi-erect, hardly raised and perfectly recumbent hair-like scales, contrast between these three types of hairs weakly expressed; hind tibiae with 1 spur; anal process not developed.

The new species (Fig. 14) differs from sympatric O. convexipterus BIAŁOOKI, 2015 (characters of this species in parentheses) in: larger body, 4.2-5.8 mm (4.6-4.9 mm); much longer and denser body vestiture: elytra with double, recumbent and semi-protruding hairs; small, dense pronotal tubercles, each one with large puncture, almost as broad as half of tubercle diameter (tubercles large, flat, with minute puncture, much lower than tubercle diameter); epistomal keels well-developed, almost symmetrical (epistomal keels unsymmetrically developed, left keel posteriorly reduced); antennae distinctly more robust: 

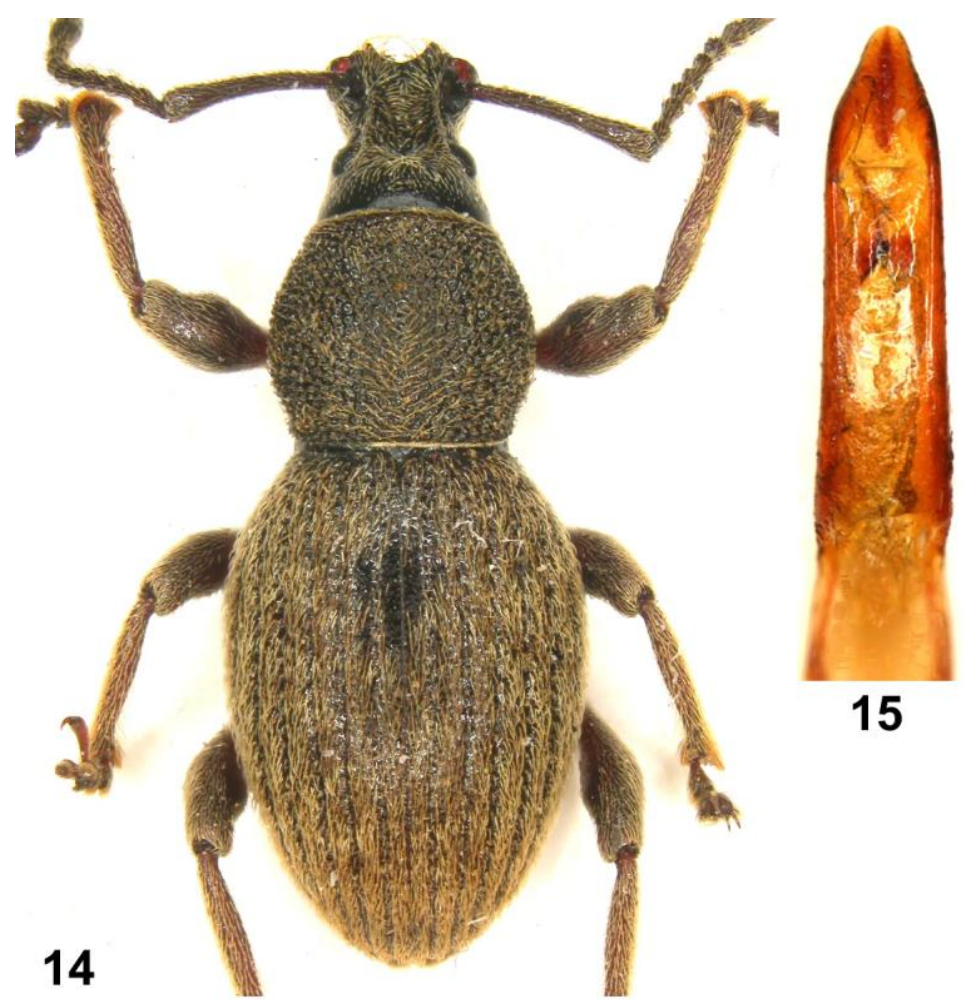

15

Figs 14, 15. O. umbraticus: 14 - male, 15 - aedagus.

funicle segments 3-5 slightly elongate, segments 6-7 isodiametric (segments 3-7 distinctly elongate); dense punctation of frons and vertex, interspaces much smaller than puncture diameter (interspaces much longer than puncture diameter); male fore tibiae with large, well visible mucro (small, hardly visible, obscured by vestiture); elytral striae with small punctures, much narrower than interstices (strial punctures large, their diameter subequally as broad as interstices; male last ventrite with anal process.

Aedeagus (Fig. 15) subparallel-sided, apex moderately elongate, top rounded.

Female differs indistinctly from male in somewhat more robust body and the first two ventrites not impressed.

\section{Ecology}

So far known from the valley of Bozdağ and western slopes of Boz Dağ 1 at altitudes of 1300-1800 m amsl; sifted from the ground litter under low vegetation, and under stones. 


\section{Etymology}

The specific epithet is the Latin adjective meaning "fond of life in the shade", though metaphorically rather than literally.

\section{Otiorhynchus (Choilisanus) sculptiventris sp. n.}

(Fig. 16)

\section{Material examined}

Holotype female, dissected: 27.05.2008 SE Turkey; Hacibaba Dă̆ı; W Karaman; leg. P. BIAŁOOKI [BIAL]. Paratypes: as ht, 6 exx.\ 13.05.2008 SW Turkey; Mt. 1982; NW Şeydişehir; leg. P. BIAŁOOKI, 4 exx. $\backslash$ 16.05.2008 SW Turkey; Belpinari Beli; SE Taşkent; leg. P. BIAŁOOKI, 4 exx.I 23.05.2009 C Turkey; Sivrihisar Geçidi; SE Aksaray, 1 ex. [BIAL; MNHW].

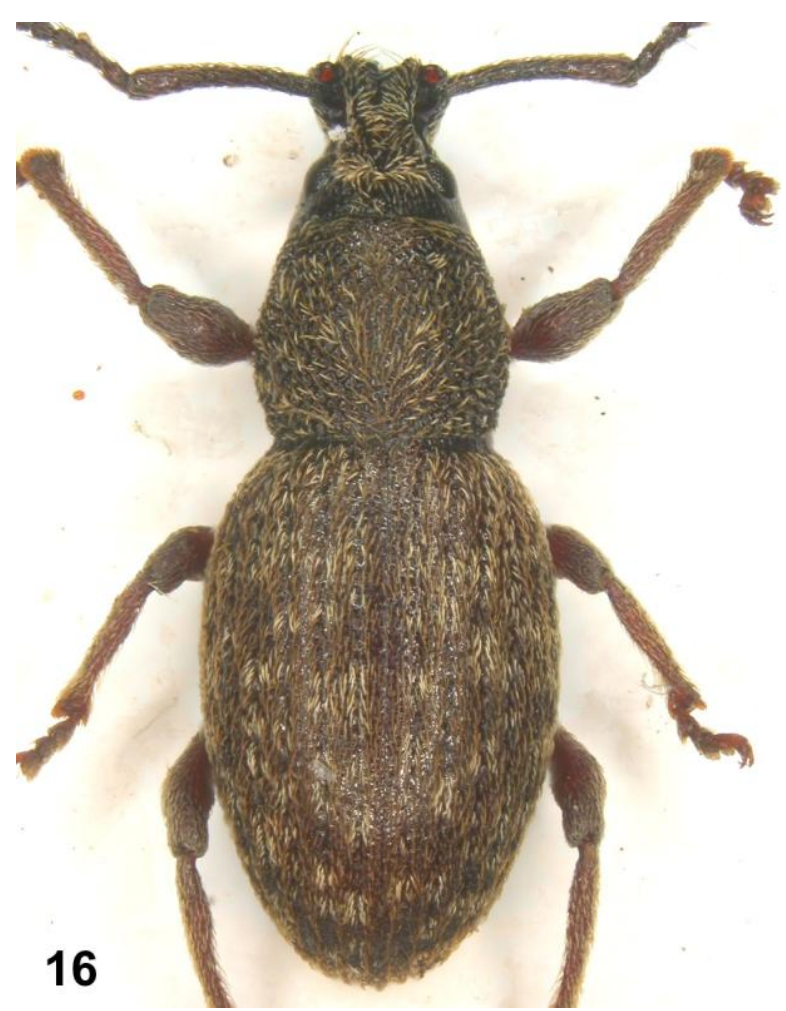

Fig. 16. O. sculptiventris, female. 


\section{Diagnosis}

The new species (Fig. 16) is best characterized by the strongly projecting pterygia; the large lateroventral excision between anterior and hind portions of rostrum; the broad hind part of dorsal wall of rostrum, $1.45 \times$ narrower than the flat frons; the large, deep frons fovea; the recumbent elytral vestiture, showing an ill-defined yet clear maculation; hind legs with a single tibial spur; ventrites 3 and 4 exceptionally strongly convex longitudinally. It differs from $O$. umbraticus in the more elongate, less rounded at sides, less convex elytra with a more convex apical declivity; a strictly recumbent vestiture, creating an irregular maculation; ventrites 3-4 unusually strongly convex transversally: anterior and posterior margins equally, very strongly elevated, as a result of which the flat (i.e. subhorizontal) surface of both ventrites is narrow. O. umbraticus has distinctly broader elytra, more arcuate at the sides, more convex in the lateral view, but with a less vaulted, perpendicular apical declivity; hairy body vestiture, clearly semi-protruding, quite uniform, with no maculation, and a well-visible integument; ventrites 3-4 are normally vaulted: the anterior portion is weakly elevated, the posterior margin subperpendicular, as a result of which the flat surface of both ventrites is broad.

\section{Description (female)}

Body length 5.0-5.4 mm (ht $5.1 \mathrm{~mm}$ ); black, antennae and legs brown, tarsi red-brown.

Head strongly transverse, at sides slightly arcuate, strongly tapered together with basal portion of rostrum; temples shorter than eye diameter; frons flat, broad, not separated from rostrum, covered with dense, rather coarse longitudinal wrinkles, and with sparse, irregular punctation, moreover with recumbent and weakly semi-erect greyish and light brown, thin lanceolate, elongate scales; frons fovea large, deep, somewhat elongate; eyes moderately big, $1.65 \times$ narrower than frons, clearly convex, somewhat elongate.

Rostrum strongly transverse, pterygial span $1.3 \times$ broader than length of rostrum; pterygia very strongly projecting; latero-ventral excision between anterior and hind parts of rostrum large; hind part of dorsal wall divergent backwardly, lateral margins well expressed; median sulcus unclear, shallow, with well expressed, thin median keel; anterior part of dorsal wall distinctly divergent anteriad, covered with dense, moderately coarse punctation; epistome symmetrical, strongly hollowed.

Antennae moderately robust, scape slightly arcuate, rather thick, apical portion weakly, gradually expanded; first two funicle segments elongate; segment 3 slightly elongate; segments 4-7 (sub)isodiametric, the last one distinctly bigger than the others; club spindlelike, $2.7 \times$ longer than broad, as long as three distal funicle segments combined.

Pronotum slightly transverse, broadest slightly behind middle, weakly convex longitudinally, moderately transversally, sides rather weakly arcuate; disc covered with small, convex, flattened tubercles; each one with rather big apical puncture bearing long, 
recumbent, yellow-brown or pale brown hair-like scale; vestiture moderately dense, in part obscuring body surface.

Elytra $1.4 \times$ longer than broad, broadest somewhat before middle, sides rather weakly, evenly arcuate, apical portion narrowly rounded; in lateral view slightly convex, somewhat flattened, apical declivity moderately convex; striae rather thin, indistinctly impressed, punctures smaller than diameter of biggest tubercles on pronotal disc, interspaces somewhat longer than diameter of punctures; interstices twice broader than striae, flat, covered with minute pinholes and subtle microrugosity, without tubercles, shining; both striae and interstices covered with rather dense, recumbent greyish, pale brown and brown lanceolate, thin, long, lanceolate scales creating unclear, irregular maculation, obscuring in large part body surface, and with brown, long, weakly arcuate hair-like scales distributed irregularly, hardly elevated, virtually recumbent.

All femora unarmed; hind legs with single tibial spur.

Ventral portion of body covered with similar vestiture as elytra, hairs thinner, sparser, distinctly raised; ventrites 3 and 4 strongly convex longitudinally, rib-like in longitudinal section, as a result flat surfaces narrow; anal ventrite $1.75 \times$ broader than long, proximal part strongly convex.

Spermatheca without ramus; lamina of spiculum ventrale subtrapezoidal, apical margin slightly excised.

Male unknown.

\section{Ecology.}

O. sculptiventris is a high alpine species. It was collected by sifting the ground litter under herbaceous vegetation and/or under Astragalus at an altitude above $1900 \mathrm{~m}$ amsl.

\section{Etymology}

The specific epithet (adjective) is coined from the Latin "sculptus" (= sculpted), and "venter" to reflect the strongly convex ventrites 3-4.

\section{Otiorhynchus (Choilisanus) plagigerulus sp. n.}

(Fig. 17)

\section{Material examined}

Holotype female, dissected (right antenna and left hind onychium missing): 09.06.2010 C Turkey, Erdaş Dağı S Nevşehir, leg. P. BIAŁOOKI [BIAL]. 




Fig. 17. O. plagigerulus, female.

\section{Diagnosis}

The new species (Fig. 17) is apparently closely related to O. aziziyensis DAVIDIAN \& GÜLTEKIN, 2015 (the two species share large femoral teeth, a unique trait in Choilisanus) but differs from that species in the large latero-ventral excision between the anterior and hind parts of the rostrum, well visible even in the dorsal view; the large, broadly triangular femoral teeth, their distal margins only indistinctly excised; the very dense, almost perfectly recumbent pronotal vestiture; the more elongate elytra, unclearly egg-shaped.

\section{Description (female)}

Body length $6.7 \mathrm{~mm}$ (holotype); entirely dark brown, legs and antennae in part much lighter.

Head strongly transverse, strongly tapered, well separated from basal part of rostrum; temples slightly shorter than longitudinal diameter of eye; frons narrow, only slightly broader than width of dorsal wall between antennal insertions, clearly separated from rostrum, covered with dense, moderately coarse punctation, interspaces shorter than 
diameter of punctures, and with light greyish, recumbent, shortly lanceolate scales; frons fovea large, elongate, deep; eyes rather small, dorso-lateral, slightly elongate, distinctly convex, not projecting.

Rostrum transverse, pterygial span $1.5 \times$ broader than rostrum minimum width; lateroventral excision between anterior and posterior parts of rostrum exceptionally large, well visible from above; anterior part of dorsal wall rather strongly divergent anteriad, covered with punctures and irregular rugosity, semi-matt; epistome large, triangular, strongly hollowed, anterior margin strongly excised, angles distinctly elevated but horns not developed.

Antennae rather robust; scape moderately, gradually thickened apicad; first two funicle segments weakly elongate, first one less than twice as long as broad, second distinctly shorter, $1.7 \times$ longer than wide; segments 3-7 moderately transverse; club spindle-like, $2.2 \times$ longer than broad, as long as three distal funicle segments combined.

Pronotum $1.2 \times$ broader than long, weakly convex longitudinally, moderately convex transversally, broadest somewhat behind middle; sides rather strongly rounded; covered with dense, rather small, low, flattened tubercles with big puncture, almost completely obscured by dense, long, much longer than on head, thin, elongate, light greyish scales; latero-ventral walls covered with low tubercles and with sparse scales, distinctly shorter than on the disc.

Elytra almost $1.5 \times$ longer than broad, indistinctly egg-shaped, sides weakly arcuate, apical portion somewhat narrower rounded than basal portion; disc longitudinally flat, transversally moderately convex, apical declivity strongly convex; striae distinctly impressed, punctures small, rounded, deep, with hair-like scale on anterior margin; interspaces subequally long as punctures diameter; interstices $1.5-2 \times$ broader than striae, slightly convex; both striae and interstices covered with dense, almost completely obscuring body surface, small, recumbent, lanceolate, coppery-brown scales; interstices also with weakly raised scales arranged in irregular 2-3 rows; striae with irregularly, sparsely distributed spots of light yellow-brown scales; apical declivity covered predominantly with light scales.

Legs moderately robust; all femora with large, broadly triangular tooth slightly sinuate on its distal margin; anterior margin of fore tibiae straight; ventral margin covered with long, straight, semi-erect yellow hairs and also with four rather large spines bearing long, stout brown seta; apex broadly rounded, somewhat curved inwards; hind tibiae distinctly arcuate dorso-ventrally, with two spurs, mucro minute, hardly perceptible; fore tarsi small, short, robust, second segment strongly transverse; hind tarsi distinctly longer, second segment moderately transverse. 
Ventral part of the body covered rather sparsely with recumbent, thin hair-like scales, and with raised longer hairs; anal ventrite flat, only basally slightly convex, $1.6 \times$ broader than long, apical portion broadly rounded.

Spermatheca typical of the subgenus, corpus somewhat elongate, ramus hardly expressed, nodulus minute, curved towards ramus.

Male unknown.

\section{Ecology}

The only specimen was sifted from ground litter under undetermined species of Fabaceae (perhaps Astragalus) at an altitude of ca $1980 \mathrm{~m}$ amsl.

\section{Etymology}

The specific name is the Latin adjective (= "showing evidence of being beaten", an allusion to the scratched elytra).

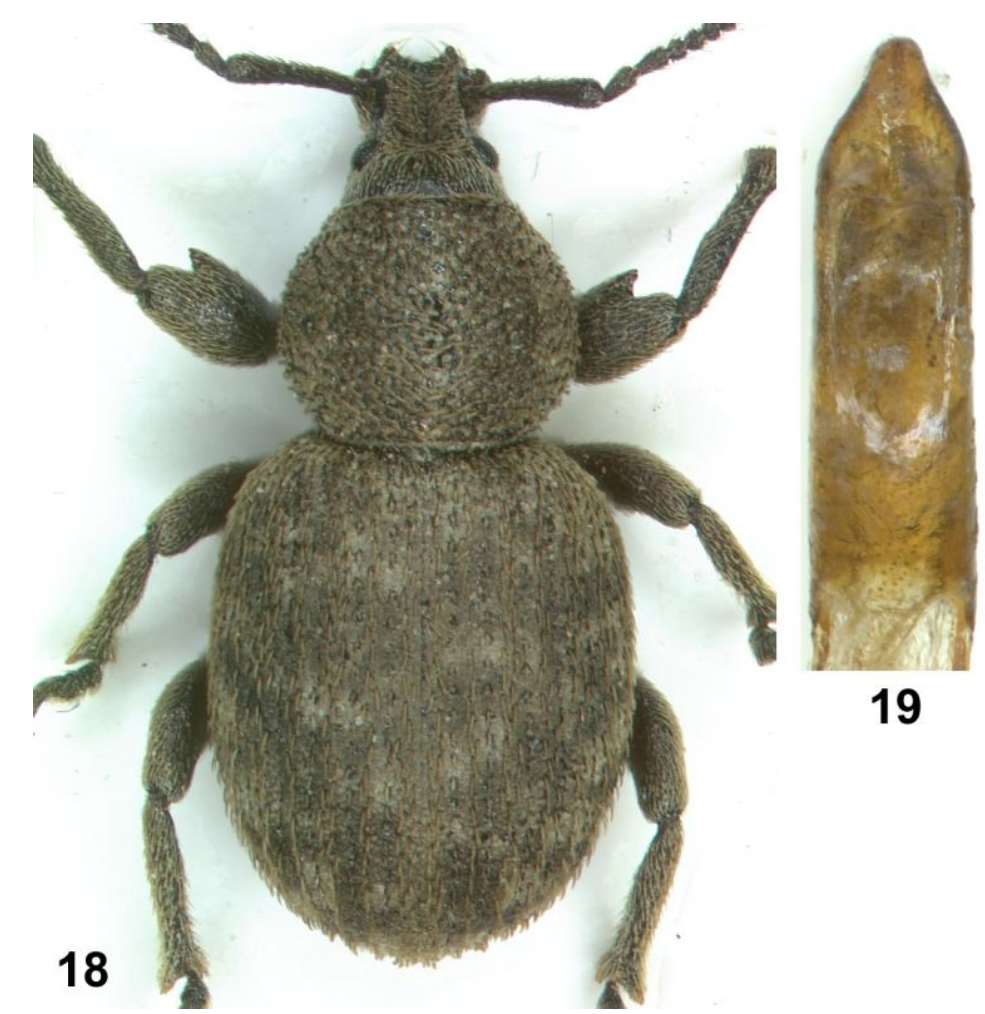

Figs 18, 19. O. imperspicabilis: 18 - male, 19 - aedagus. 


\section{Otiorhynchus (Choilisanus) imperspicabilis sp. n.}

(Figs. 18, 19)

\section{Material examined}

Holotype male, dissected (right fore tarsus missing): 02.06.2010 SW Turkey, Katrancik Dağları, Mt. 2334 m, S Burdur, leg. P. BıAŁOOKI [BIAL]. Paratypes: as ht, 4 exx. [BIAL].

\section{Diagnosis}

The most distinctive features of the new species are: short, broad body (in outline somewhat similar to e.g. Otiorhynchus weisei), covered with imbricate broad scales completely obscuring the body surface, and with elongate, several $\times$ longer than wide, arcuate, semi-erect scales; very short, robust legs; the presence of epistomal horns; all femora with a large tooth slightly dentate on the outer margin, the apex broadly rounded; the lamina of the spiculum ventrale very strongly excised; the short, broad ovipositor. $O$. imperspicabilis sp. n. only formally refers to O. plagigerulus, sharing with that species the large, slightly excised femoral teeth. In fact, both species represent disparate groups within Choilisanus owing to the very short epistome with the single crescentic keel typical of the subgenera Tournieria, Pocodalemes etc.; the very strongly excised apical margin of the lamina of the spiculum ventrale; and the subcircular imbricate elytral scales. All these characters are unique within Choilisanus, in which $O$. imperspicabilis has been only tentatively placed. Its systematic position requires further study.

\section{Description (male)}

Body length 4.7-4.8 mm (ht $4.8 \mathrm{~mm}$ ); black, antennae and tibiae in part dark brown.

Head moderately transverse; temples subequally long as longitudinal diameter of eye; frons covered with rather large, dense punctures, and with broad, recumbent and somewhat raised, elongate, predominantly apically truncate scales largely obscuring body surface; frons fovea well-developed; eyes somewhat elongate, moderately convex.

Rostrum weakly transverse; pterygia rather large, strongly projecting, pterygial span $1.3 \times$ broader than minimum rostrum width; hind part of dorsal wall of rostrum almost in a plane with frons, divergent backwards, slightly convex longitudinally, surface covered with irregular, dense punctation, largely obscured by vestiture similar to that on head; lateral margins moderately sharply expressed, rounded; anterior part of dorsal wall rather weakly divergent anteriad, densely covered with rough punctation; epistome short, transverse, hollowed, its anterior margin distinctly excised, keel broadly arcuate, strongly extended anteriad behind pterygia and upwards forming horns.

Antennae short, fairly robust; scape straight, weakly, evenly thickened apicad; first two funicle segments each about $2 \times$ longer than wide, the first somewhat broader; segments 
3-5 weakly transverse; segments 6-7 moderately transverse; club elongate egg-shaped, twice as long as broad, as long as almost four distal funicle segments combined.

Pronotum large (Fig. 18), $1.25 \times$ broader than long, moderately convex transversally, weakly vaulted longitudinally, sides strongly, evenly rounded; broadest at middle; disc covered with large, dense, strongly flattened tubercles, in part almost reduced to punctation; relief almost completely obscured by vestiture: large, round or weakly elongate recumbent scales very densely arranged, and more sparse, semi-protruding, elongate, several $\times$ longer than wide, about twice longer than recumbent scales, with an apex predominantly truncate; lateroventral portions of prothorax covered with low, somewhat unclear tubercles, and with sparse, thin, elongate, truncate scales.

Elytra short, $1.25 \times$ longer than broad, robust, at sides weakly arcuate, broadest at midlength, apical portion very broadly rounded; in lateral view anterior half completely flat (also transversally), apical half strongly convex; striae narrow, in part (mainly on apical declivity) somewhat impressed, punctures small, somewhat elongate; interstices flat, $3 \times$ broader than striae; both striae and interstices covered with dense, overlapping, circular, or weakly elongate recumbent, light brown scales completely obscuring body surface; interstices also with irregular 1-2 rows of semi-protruding, arcuate, coppery-brown scales; much lighter recumbent scales cause unclear, irregular maculation, best visible on apical declivity.

Legs short and stout; fore femora strongly swollen, much larger than the other ones, with large, high tooth with its outer margin slightly dentate; middle and hind femora with distinctly smaller, but nevertheless big tooth; fore tibiae short, straight, apex expanded both inside and outside, broadly rounded; fore tarsi short, stout, second segment strongly transverse; hind tibiae short, strongly flattened laterally, strongly expanded apicad, with two spurs; tarsi somewhat longer and narrower than fore tarsi.

Ventral part of the body covered with semi-protruding, moderately dense, thin, elongate coppery hair-like scales; body surface well visible, shining, covered with rather dense, small punctures; first two ventrites weakly impressed; anal ventrite $2.15 \times$ broader than long, with shallow, but well visible apical impression.

Aedeagus (Fig. 19) with median lobe distinctly longer than apodemes, broadest basally, evenly, weakly tapered apicad; in lateral view moderately arched.

Female differs from male in lack of epistomal horns, and first two ventrites not impressed.

\section{Ecology}

All specimens collected under stones at an altitude of ca $2300 \mathrm{~m}$ amsl in relatively moist grassland. 


\section{Distribution}

The only known locality is situated in Katrancik Dağları in the region of Isparta. Etymology. The specific name is the Latin adjective (= "inscrutable, inapprehensible"), an allusion to the unclear systematic position of the new species.

\section{REFERENCES}

BIAŁOOKI P.Z. 2015a. Descriptions of new taxa in Otiorhynchus GeRmAR, 1822 (Coleoptera: Curculionidae: Entiminae: Otiorhynchini). Polish Journal of Entomology 84(2): 85-99.

BiAŁOOKI P.Z. 2015b. Descriptions of new taxa of Otiorhynchini and related tribes (Coleoptera: Curculionidae: Entiminae) from Middle East and Balkans. Israel Journal of Entomology 44-45: $13-50$.

BoHEMAN C. 1842. [in:] C.J. SCHÖNHERR. Genera et species curculionidum, cum synonymia hujus familiae. Species novae aut hactenus minus cognitae, descriptionibus a Dom. Leonardo Gyllenhal, C.H. Boheman, O.J. FÅHraeus et entomologis aliis ilustratae. Tomus septimus. Pars prima. Roret, Parisiis, Fleischer, Lipsiae.

DANIEL K., DANIEL J. 1902. Nova, von Hauptmann v. BoDEMEYER in Kleinasien gesammelt. Münchener Koleopterologische Zeitschrift 1(3): 101-113.

DAVIDIAN G.E., Gültekin L. 2015a. Contribution to the knowledge of the weevil subgenus Choilisanus REITTER, 1912, genus Otiorhynchus GERMAR, 1822 (Coleoptera: Curculionidae: Entiminae). Journal of Insects Biodiversity 3(4): 1-13.

Davidian G.E., Gültekin L. 2015b. Two new species of Otiorhynchus Germar, 1822 (Coleoptera: Curculionidae: Entiminae) from eastern Turkey with new taxonomical contributions to the subgenus Choilisanus REITTER, 1912. Journal of Insect Biodiversity 3(10): 1-14.

DAVIDIAN G.E., KESKIN B. 2010. To the knowledge of the weevil genus Otiorhynchus GERMAR, 1824 [sic!], subgenus Choilisanus REITTER, 1912 (Coleoptera: Curculionidae). Russian Entomological Journal 19(1): 61-65.

Germar E. 1822. Fauna Insectorum Europae. Fasciculus 13. Kümmelii, Halae.

GYllenhAl L. 1834. [in:] C.J. SCHÖNHERR. Genera et species curculionidum, cum synonymia hujus familiae. Species novae aut hactenus minus cognitae, descriptionibus a Dom. Leonardo Gyllenhal, C.H. Boheman, O.J. FÅHraeus et entomologis aliis ilustratae. Tomus septimus. Pars prima. Roret, Parisiis, Fleischer, Lipsiae, 329-673.

Magnano L, Alonso-Zarazaga M.A. 2013: Otiorhynchini. [in:] I. LöBl, A. SmetanA (eds.). Catalogue of Palaearctic Coleoptera, vol. 8. Brill, Leiden, 302-347.

REITTER E. 1895. Neue Curculioniden aus der asiatisch-palaearctischen Fauna. Wiener Entomologische Zeitung 14: 21-31.

REITTER E. 1898. Neue Coleopteren aus Europa und den angrenzenden Ländern. Deutsche Entomologische Zeitschrift 29(2): 337-360.

REITTER E. 1912. Übersicht der Untergattungen und der Artengruppen des Genus Otiorrhynchus GERM. (Bestimmungstabelle nr. 66). Wiener Entomologische Zeitung 31: 45-67. 
REITTER E. 1913. Bestimmungstabellen der Otiorrhynchus-Arten mit ungezähnten Schenkeln aus der palaearktischen Fauna. Wiener Entomologische Zeitung 32: 25-118.

STIERLIN W.G. 1884. Beschreibung einiger neuer Rüsselkäfer. Mittheilungen der Schweizerischer Entomologische Verein 7: 36-43

Received: 12 December 2015

Accepted: 29 January 2016 